удК

$327(497.1) " 196 "$

$327(497.1: 470)^{\prime \prime} 196 "$

327.56::351.88(4)"196"

Оригиналан научни рад

Примљен: 7. 1. 2017.

Прихваћен: 16. 1. 2017.

\author{
Ljubodrag DIMIĆ \\ Faculty of Philosophy, University of Belgrade \\ ljubodrag_dimic@yahoo.com
}

\title{
Yugoslavia and Security in Europe during the 1960s (Views, Attitudes, Initiatives)*
}

\begin{abstract}
The issue of peace and security in Europe was one of the key issues of the Yugoslav foreign policy during the 1960s. Yugoslavia supported initiatives for the suspension and prohibition of nuclear testing, destruction of obsolete military arsenal, nuclear non-proliferation, achieving global security, recognition of Oder-Neisse border and a need for the acceptance of two German states. The article is based on Yugoslav and Soviet published and unpublished sources and relevant domestic and foreign literature.
\end{abstract}

Key words: Yugoslavia, Europe, USSR, US, Cold War, security, nuclear weapon, German issue, Josip Broz

The renewal of nuclear testing, construction of the Berlin Wall, conflicts between military blocs, assassinations, crises, revolutions, ideological conflicts and interventions, fractures and conservative colonial regime... were some of the problems arising from the controversial nature of

This article has been written within the framework of the scholarly project: Serbs and Serbia in a Yugoslav and International Context: internal Development and Position in European/International Community (No. 47027), financed by the Ministry of Education, Science and Technological Development of the Republic of Serbia. 
the Cold War in the early 1960s. ${ }^{1}$ The key issues of security and cooperation needed to be negotiated. Non-aligned countries presented this need to the representatives of the great powers (Khrushchev and Eisenhower) at the $15^{\text {th }}$ Session of the UN General Assembly in $1960 .^{2}$ During the 1960s the great powers showed a great interest in conclusion of partial agreements on control of the nuclear weapon thus securing themselves from the opposing side. They started the talks on suspension and prohibition of nuclear tests, destruction of obsolete military arsenal, nuclear non-proliferation, and achieving global security. ${ }^{3}$ The initiatives for the establishment of a nuclear-free zone in Northern Europe (Finland, Norway, Sweden, and Denmark), ${ }^{4}$ denuclearization of the Mediterranean, ${ }^{5}$ "freezing" of hydrogen and nuclear weapons in Central Europe, ${ }^{6}$ stability and security in Eu-

1 Џон Л. Гедис, Хладни рат. Ми данас знамо, (Београд: Clio, 2003); Od Arne Vestad, Globalni hladni rat, (Beograd: Arhipelag, 2008); Henri Kisindžer, Diplomatija, 1-2, (Beograd: Verzal press, 1999); Волтер Лакер, Историја Европе 1945-1992, (Београд: Clio, 1999); The Cambridge History of the Cold War, I, edited by Melvyn P. Leffler and Odd Arne Westad, (Camridge: Cambridge University Press, 2010).

2 One of five signatories of the mentioned appeal was Josip Broz Tito. Драган Богетић, Љубодраг Димић, Београдска конференција несврстаних земаља (1-6. септембар 1961), (Београд: Завод за уџбенике, 2013), 235-242.

3 For more information, see: Ljubivoje Aćimović, Problemi bezbednosti i saradnje $u$ Evropi, (Beograd: Institut za međunarodnu politiku i privredu, 1978); Radovan Vukadinović, Evropska sigurnost i suradnja, (Zagreb, Globus, 1976); Radovan Vukadinović, Lidija Čehulić Vukadinović, Davor Božinović, NATO euroatlanska integracija, (Zagreb: Topical, 2007), 65-132; Lidija Čehulić Vukadinović, Euroatlantizam i suvremeni međunarodni odnosi, (Zagreb: Politička kultura, 2010), 61-87; Marco Rimanelli, The A to Z of NATO and other International Security Organizations, (Lanham-Toronto, Plymonth: Scarecrow press, 2009), LXXVI-LXXXI; The Cambridge History of the Cold War, II, edited Melvyn P. Leffler and Odd Arne Westad, (Cambridge: Cambridge University Press, 2010).

$4 \quad$ This idea was elaborated by Finnish President Urho Kekkonen in May 1963.

5 In May 1963, the USSR pledged to eliminate all forms of atomic weapons, close the military bases in the Mediterranean and ban the production of nuclear weapons, as well as those present at the Conference of Non-Aligned Countries, held in Algiers in 1964. One of the promoters of the document was Yugoslavia. Its representatives submitted a proposal to require the Government of the Mediterranean countries to make Mediterranean, a nuclear-free zone. The great forces were also asked to remove nuclear arsenals from the area of the Mediterranean and close military bases.

6 The idea was first propagated by Secretary of Polish United Workers' Party Vladislav Gomulka in December 1963 and February 1964 (the so-called “Gomulka Plan”). It involved the establishing of nuclear-free zones, the cessation of production of nuclear weapons and the international control of the whole process of denuclearization. 
rope, ${ }^{7}$ holding the Conference on Security and Cooperation, ${ }^{8}$ new forms of NATO presence in Europe, ${ }^{9}$ Europe's independence from US, ${ }^{10}$ became increasingly frequent. ${ }^{11}$ Yugoslav state leadership had its own way of thinking, firm attitudes, and concrete initiatives regarding important issues of European future.

During the 1960s, Europe was filled with contradictions and conflicts and Yugoslavia was searching its place therein. The main interest of a Yugoslav state was the stability of foreign policy. The opposed war blocks widely respected its independence and territorial integrity. The West ceased to expect indirect involvement of Yugoslavia in its military-political structure. ${ }^{12}$ The Balkan Alliance, as a potential military pact,

$7 \quad$ The idea was presented by Andrei Gromyko in the autumn of 1964, at the 19 th session of the UN General Assembly.

8 The idea was launched by the Political Consultative Committee of the Warsaw Pact in January 1965. A year later, in January 1966, the political leadership of the German Democratic Republic came forward with a proposal of measures for reducing tensions and establishing security in Europe. The need for such a meeting was confirmed by the $23^{\text {rd }}$ Congress of the Communist Party of the Soviet Union (CPSU) held in March 1966. Political Consultative Committee of the member states of Warsaw Pact issued a Declaration on strengthening of peace and security in Europe in July 1966. In the fall of 1966, at the $21^{\text {st }}$ session of the UN General Assembly, a special resolution was passed which regulated the exploration and use of the space, which is the cosmic space was declared a nuclear-free zone. In late April 1967, the Conference of European Communist and Workers' Parties held in Karlovy Vary made a special "Declaration on Peace and Security in Europe".

9 This was discussed at the meetings of NATO member states from January to June 1965 without informing the public.

10 These ideas were particularly prominent in France. More on French politics: "France 'Gaullism' and the Cold War", The Cambridge History of the Cold War, II/158-178.

11 For more information, see: D. Đokić, „Kontrola naoružanja u Evropi (predlozi i inicijative 1946-1969)“, Materijali o evropskoj bezbednosti, publikacija DSIP-a, (Beograd, 1969); Diplomatic Archives of the Ministry of Foreign Affairs of the Republic of Serbia (Diplomatski arhiv Ministarstva spoljnih poslova Republike Srbije - DAMSPRS), Political Archives (Politička arhiva-PA), 1966, f-154, dok. 2, br. 46194, Problemi evropske bezbednosti i inicijative istočnoevropskih zemalja, 2.3.1966; V. Vuksanović, „Značajniji predlozi i inicijative za rešenje pitanja evropske bezbednosti i saradnje“, Materijali o evropskoj bezbednosti, 106-108.

12 More on relations between Yugoslavia and the West: Dragan Bogetić, Jugoslavija i Zapad 1952-1955, (Beograd: Službeni list SRJ, 2000); Darko Bekić, Jugoslavija u hladnom ratu (Odnosi s velikim silama 1948-1955), (Zagreb: Globus, 1988). 
was almost completely "off". ${ }^{13}$ The fear of the West that Yugoslavia was a "Trojan horse" of the world communism was no longer real. ${ }^{14}$ There was a belief that Yugoslavia could erode the monolithic structure of the Eastern Bloc countries. On the other hand, Yugoslavia resisted the harsh pressures for inclusion in the "camp" of socialist countries. ${ }^{15}$ The accusations of revisionism no longer had the form of campaign nor the potential they had in the late 1950s and early 1960s. The Party and State leadership was in favour of both East and West. ${ }^{16}$ Therefore, they stood away from all the initiatives that could be interpreted as siding with one of the parties in conflict, especially those that created the illusion of unilateral and concerted action with the parties of socialist countries. ${ }^{17}$ The policy of non-alignment and one of the leading positions he had in the movement,

13 More on relations between Yugoslavia and the Balkan Pact: Balkanski pakt, Zbornik dokumenata, priredili M. Terzić, M. Basara, D. Tasić et al., (Beograd: Vojnoistorijski institut, 2005); Balkanski pakt, Zbornik radova, ur. Nemanja Milošević, (Beograd: Institut za strategijska istraživanja, 2009).

14 Lorejn Lis, Održavanje Tita na površini. Sjedinjene države, Jugoslavija i hladni rat, (Beograd: BMG, 2003).

15 For more information, see: Југославија и СССР. Сусрети и разговори на највишем нивоу руководилаца Југославије и СССР 1946-1964, приредили Љ. Димић, М. Милошевић, А. С. Стикалин и др., (Београд: Архив Југославије, 2015); Југословенско-совјетски односи 1945-1956, Зборник докумената, приредили Љ. Димић, М. Милошевић, Ђ. Борозан, (Београд: Министарство спољних послова, 2010); Đ. Tripković, Jugoslavija-SSSR 1956-1971, (Beograd: Institut za savremenu istoriju, 2013); Lj. Dimić, Jugoslavija i hladni rat, Ogledi o spoljnoj politici Josipa Broza Tita, (Beograd: Arhipelag, 2014). For more information on USSR foreign policy, see: Giuseppe Boffa, Povijest Sovjetskog Saveza. Od domovinskog rata do položaja druge velesile. Staljin i Hruščov, II, (Opatija: Otokar Keršovani, 1985); Mihail Geler i Aleksandar Nekrič, Utopija na vlasti. Istorija Sovjetskog Saveza, (Podgorica: CID, 2000); Vojtech Mastny, "Soviet foreign policy 1953-1962", Cambridge History of the Cold War, (Cambridge, 2010), 312-333.

16 Dragan Bogetić, Nova strategija spoljne politike Jugoslavije 1956-1961, (Beograd: Institut za savremenu istoriju, 2006); Југославија и СССР. Сусрети и разговори на највишем нивоу руководилаца Југославије и СССР 1964-1980, приредили Љ. Димић, А. Животић, А. Аникејев и др., (Београд: Архив Југославије, 2016); Dimić, Jugoslavija i hladni rat.

17 Archives of Yugoslavia, Office of the President of the Republic (Arhiv Jugoslavije, Kabinet predsednika Republike - AJ, KPR), I-4-d, Zabeleška o razgovoru državnog podsekretara za inostrane poslove V. Mićunovića sa ambasadorom SSSR Valjkovim 25. 11. 1954; Tekst jugoslovenskog odgovora na notu Vlade SSSR od 13. 11. 1954; Archives of Yugoslavia, Central Committee, The League of Communists of Yugoslavia (Arhiv Jugoslavije, Centralni komitet Saveza komunista Jugoslavije AJ, CK SKJ), IX, $144 / \mathrm{VI}-3,8,9,15,19,22,26,34,37,42,46$. 
gave J. B. Tito the capacity to deal with the world politics ${ }^{18}$ which was contrary to the size, economic potential, military power and internal stability of the country. The elimination of the fear of foreign invasion indirectly influenced the development of internal relations, calculations within the party leadership, "loosening" of the Yugoslav Federation, opening of the national question, independence of the republics, and a new constitution$\mathrm{al}$ and legal system of the country. The internal crisis was deep: state and party, ideological and organizational, political and economic, social and moral. According to the party leadership, it lasted more than a decade, and shook the foundations of the party in power, overcoming the state, destroying institutions and society, and threatening international stability, and causing numerous controversial problems. ${ }^{19}$

Yugoslav foreign policy during the 1960s was influenced by several factors. Cooperation with the countries of Afro-Asian space, i.e. the world that emerged from the anti-colonial revolutions and existed way from Europe, the USSR, and the United States which were divided by the cold war, and had similar problems as Yugoslavia, most directly influenced the Yugoslav foreign policy at the beginning of the $1960 \mathrm{~s} .{ }^{20}$ The en-

18 Богетић, Димић, Београдска конференција несврстаних земаља, 235-242.

19 For more information on a crisis in Yugoslav state and society during the 1960s, see: Почетаккраја СФРЈ. Стенограми и други пратећи документи проширенеседнице Извршног комитета СК СКЈ одржане од 14. до 16. марта 1962, (Београд: Архив Југославије, 1998); VII конгрес SKJ, (Београд, 1964); Четврта седница CK SKJ, (Београд: Архив Југославије 1999); Четрнаеста седница СК СК Србије, (Београд, 1968); Branko Petranović, Momčilo Zečević, Jugoslovenski federalizam. Ideje i stvarnost, II, (Beograd: Prosveta, 1987); Бранко Петрановић, Југословенско искуство српске националне интеграције, (Београд: Службени лист, 1993); Dušan Bilandžić, Hrvatska moderna povjest, (Zagreb: Golden marketing, 1999); Љубодраг Димић, Историја српске државности. Србија у угославији, III, (Нови Сад: Српска академија наука и уметности (огранак у Новом Саду), „Беседа“, издавачка установа православне епархије Бачке и Друштво историчара јужнобачког и сремског округа, 2011).

20 For more information, see: Leo Mates, Nesvrstanost. Teorija i savremena praksa, (Beograd: Institut za međunarodnu politiku i privredu, 1970); Leo Mates, Međunarodni odnosi socijalističke Jugoslavije, (Beograd, 1976); Bojana Tadić, Olivera Bogetić, Dragan Bogetić, Osobenosti i dileme nesvrstanosti, (Beograd: Komunist, 1982); Olivera Bogetić i Dragan Bogetić, Nastanak i razvoj pokreta nesvrstanosti, (Beograd: Export Press, 1981); Dragan Bogetić, Koreni jugoslovenskog opredeljenja za nesvrstanost, (Beograd: Institut za savremenu istoriju, 1981); Od Arne Vestad, 
gagement in non-alignment policy pushed European issues into the background of the Yugoslav foreign policy interests. This, of course, did not mean that the Yugoslav state leaders and the Yugoslav diplomacy "left" Europe and stopped being interested in its problems. By dealing with the issue of world peace, resolving conflicts by peaceful means, prohibition of spreading nuclear weapons and nuclear testing, curbing the arms race, advocating the peaceful and active coexistence of countries with different political systems and ideological beliefs, Yugoslavia most directly contributed to stabilizing the situation in Europe. ${ }^{21}$ Since Yugoslavia was inseparably linked to the European soil, its stability most directly depended on its relationship with the East and West, as well as on easing the "tensions" between the East and West in a divided Europe. The decrease of the European crisis and peace across the continent, were of critical importance for Yugoslavia.

During the preparations for the Conference of Heads of State and Government of the Non-Aligned Countries, held from September 1 to 6 1961 in Belgrade, Yugoslav diplomacy wanted to give importance to Berlin and Germany issue, and the Conference itself to contribute to overcoming the current situation. Especially because in the time immediately preceding the conference, the Cold War was in full swing. Confrontations between the East and West regarding the Berlin issue resulted in raising the Berlin Wall around mid-August $1961{ }^{22}$ The World peace was threatened by military interventions of the colonial powers in Congo, Angola, Vietnam, Laos and the escalation of the crisis over Cuba. The nuclear moratorium was not respected. The information about the renewal of nuclear testing, the events in Berlin and the measures yet to be taken by each of the parties to the conflict, reached Belgrade directly from first-hand sources. Yugoslav diplomats were aware of the fact that despite diplomatic rhetoric, sometimes sharp, sometimes conciliatory, both

Globalni hladni rat, (Beograd: Arhipelag, 2009); Богетић, Димић, Београдска конференција несврстаних земаља.

21 Ibid.

22 For more information on German issue, see: Dirk Verheyen, The German Questions: A Cultural, Historical and Geopolitical Exploration, (Boulder - San Francisko - Oxford, 1991); William Glenn Gray, Germany's Cold War. The Global Campaign to Isolate East Germany 1949-1969, (Chapel Hill - London: UNC Press, 2003). 
sides in the conflict made the peaceful solution of the problems quite difficult. For Yugoslavia, the Berlin issue was not a regional problem, but a crisis that could produce a new war. In the talks with the US representatives, Belgrade pointed out that the rearmament of the Federal Republic of Germany was a mistake, advocated recognition of Oder-Neisse line, pointing to the need for acceptance of the two German states. For these reasons, Yugoslav diplomacy appealed to the United States and the Soviet Union to sit at the negotiating table and constructively resolve existing problems. When it comes to the Soviet Union, their decision on the renewal of nuclear testing was considered wrong, and the fact that it was happening on the day of the Conference of Non-Aligned Countries, counterproductive and bad. ${ }^{23}$ Tito believed that the existence of two German states was a reality, advocated the recognition of existing state and tried to persuade the heads of state and government of influential non-aligned countries to recognize East Germany as a separate state. Tito accused the great powers because after 1945, when it comes to Germany, they did not choose the path of democratization but militarization. Armed Germany was not a factor of security in Europe. In Tito's opinion, the most effective way to resolve the Germany and Berlin Issue was through negotiations, removing elements that potentially encouraged conflict, finding solutions that could lead to peaceful and constructive cooperation, without prejudging the final outcome. He opposed the efforts of "preserving" the question of Germany believing that such solutions could activate a crisis point and lead to new conflicts. ${ }^{24}$

With equal enthusiasm Yugoslavia was engaged on the issue of suspension of the arm race, banning nuclear testing, and condemnation of colonialism. However, when condemning Soviet nuclear testing, Josip Broz was clear, but "moderate". This political move led to establishing better cooperation with Moscow and tightening the relations with the West in the coming years. ${ }^{25}$ However, the Yugoslav views presented in September 1961, most directly contributed to the consolidation of the peace in the world, and therefore the cooperation and security in Europe.

23 Богетић, Димић, Београдска конференција несврстаних земаља, 326-396.

24 Ibid.

25 AJ, KPR (837), I-4-a/ Beogradska konferencija, Zabeleška o zaključcima sa sastanka jugoslovenske delegacije održanog 25. 8. 1961; AJ, KPR (837); I-5-b SAD, Zabeleška o razgovoru državnog sekretara Koče Popovića sa ambasadorom SAD Džordžom Kenanom od 31. 8. 1961; Богетић, Димић, Београдска конференција несврстаних земаљь, 371-396, 447-448. 
The attitudes advocated by Yugoslavia at the Conference of Heads of State and Government of Non-Aligned Countries (September 1961), encouraged the recovery of "frozen" relations with the USSR. In the spring 1962, the Soviet state and party leadership re-examined their policy towards Yugoslavia. Due to the internal problems faced by Yugoslavia at that time, ${ }^{26}$ the Soviet side wanted to know "to which limit Yugoslavia was ready to go" in mutual cooperation. At the same time, there was a "crystallization" and long-term defining of the Yugoslav policy towards the USSR. Belgrade was not ready to change the general framework of its foreign policy. Summing up the overall policy toward the Soviet Union, in April 1962, the Yugoslav state leadership thought that the Soviets "should be opposed" if "the essence of our policy" was at stake, i.e. where accepting Soviet tendencies could cause damage to our own political interests. In such circumstances, Gromyko and Brezhnev visited Yugoslavia in April and September/October 1962 respectively.

Gromyko's visit to Yugoslavia came after the failure of negotiations of the great powers in Geneva, so the main issues discussed were Germany, Berlin and disarmament. On that occasion, the Yugoslav side was informed that the US agreed to respect the sovereignty of East Germany, after specifying the free entry to West Berlin. Very important was the information that the US would not provide atomic weapons to West Germany, if other countries not having this type of weapon "waived their right therein" which idea was opposed by the USSR. Other issues discussed in Geneva that helped Yugoslav side define its views and policies were: non-aggression pact, the signing of peace agreements, the issue of German borders, the withdrawal of foreign troops from military bases in the territory of other countries, the US proposal on reducing rocket weapons by $30 \%$, efforts of the United States and the consent of Soviet Union to continue bilateral talks and supress De Gaulle and Adenauer. Since the main issue to be solved in the future was the issue of "western army" in West Berlin, Tito was of the opinion that it should be replaced by the troops of neutral countries or the UN forces. The Yugoslav side thought that Berlin as a political issue was outdated. It agreed with the assessment of the Soviets that "disarmament situation was dark." It also

26 For more information on the gravity of internal situation, see: Димић, Историја српске државности, III/367-370. 
advocated further negotiations, "flexible" approach to resolving issues that posed a threat to peace. Tito advised his interlocutor that, if the US reintroduced nuclear testing, the Soviets should not rush in doing the same. He was convinced that nuclear testing would not change the "basic balance" of political and military powers in the world; hence, Yugoslavia remained persistent in advocating the abolishing of all kinds of nuclear tests. Tito believed that "disarmament was the most important issue" and that Berlin issue was just a "trifle". ${ }^{27}$

The visit of Leonid Brezhnev to Yugoslavia and his meeting with Josip Broz Tito (September 9 - October 4,1962) definitely marked a new stage in relations between Yugoslavia and the Soviet Union. It was agreed that relations must be further developed on realistic basis, gradually and without illusions. Observing international situation, Brezhnev put special emphasis on the role of the USSR in the struggle for the peace in the world. He spoke about the policy of disarmament, nuclear tests, and exploring the cosmos. As for the "European issues", he mentioned Berlin and the opinion of the Soviet side "that a peace treaty should be signed by all the countries that fought with Germany." In this way, according to the Soviets, "new adventures of German militarism" would be definitely stopped. In his talks with Brezhnev, Tito did not refer to the problems faced by Europe. Being familiar with the remarks made by the Soviets, he specifically referred to the policy of non-alignment noting that developing countries "played an important role not at the expense but rather to the benefit of the Soviet Union." On that occasion, Tito rejected the objections that Yugoslavia undermined the reputation of the USSR in the Third world countries. He told Brezhnev that the Soviets must feel "their preferences" regardless of the fact that Yugoslavia did not belong to any bloc. Pointing out that in recent years Yugoslavia acquired "reputation, trust and position that others did not have or could not acquire," Tito directly alluded to the benefits Moscow could have. He warned that the Yugoslav policy of non-alignment should be understood as a policy "in the interest of the general common goal" (that is, socialism) and "world peace" and that Yugoslavia then had "much more benefits than it had with them" because in that case everybody would lose. The message was clear - "You

27 AJ, KPR, I-3-a/101-33, Zabeleška o razgovoru J. B. Tita sa ministrom inostranih poslova SSSR-a A. Gromikom od 17. 4. 1962; AJ, KPR, I-3-a/ 101-33, Zabeleška o razgovoru potpredsednika SIV-a E. Kardelja sa ministrom inostranih poslova SSSR-a Andrejom Gromikom od 19.4.1962. 
have to take care of us and see us as your friends." 28 The talks in Belgrade enabled, after six years, a new meeting between Tito and Khrushchev.

In early December 1962, after the years of conflict and different opinions "Yugoslav state leadership, led by J. B. Tito, once again found itself in Moscow. The circumstances under which the meeting took place enabled the "widest political exchange of views on major issues of interest to international relations and relations between the two socialist countries." ${ }^{29}$ The talks they had on that occasion led the Yugoslav national leadership to the undivided impression that the Soviet Union after Stalin's death, aware of its responsibilities and power, opted for lasting peace, resolution of international disputes by peaceful means, elimination of war in international relations, and peaceful building of a communist society. The undisputable military forces and nuclear potential of the USSR were no longer the subject of speculations about the new world war which would abolish capitalism. The conclusion of the Yugoslav side was that the first country of socialism no longer based its internal nor external orientation on the element of "force." The Yugoslav state leadership was encouraged by the fact that the Soviet leadership "resolutely opposed dogmatic currents" and considered dogmatism as "the main impediment to the implementation of a peaceful course of socialist forces." ${ }^{30}$

When it comes to European issues, both sides remained on the positions set out in the previous meetings of Tito with Gromyko and Brezhnev. There were certain changes in the field of cooperation between the socialist countries. Defining mutual relations and relations among socialist countries, Khrushchev tried to demonstrate to Tito, once again, that "imperialistic" part of Yugoslavia evaluated the extent to which it contributed to breaking the "camp" of socialist countries. Noting the differences between attitudes in the Warsaw Pact and the "camp", Khrushchev did not exclude the possibility of Yugoslavia joining the "camp", but also keeping its place within the circle of Non-Aligned Countries. ${ }^{31}$ The

28 More about the meeting in: AJ, KPR, I-3-a/101-40, Zabeleške o razgovorima jugoslovenske i sovjetske delegacije 24. 9. - 4.10. 1962; AJ, KPR, I-3-a/101-40, Zajedničko saopštenje o zvaničnoj poseti Predsednika Prezidijuma Vrhovnog sovjeta SSSR L. Brežnjeva FNRJ.

29 AJ, KPR, I-2/16-1, Informacija o poseti generalnog sekretara SKJ i predsednika FNRJ J. B. Tita SSSR-u decembra 1962.

30 Ibid.

31 The Russian State Archive of Contemporary History (РГАНИ), Ф. 52, Он. 1, Д. 595, Л. 1-20; AJ, KPR, I-2 /16-1, Informacija o poseti generalnog sekretara SKJ i predsednika FNRJ J. B. Tita SSSR-u decembra 1962. 
conclusion of Yugoslav side, which very much stood out from the content of the talks, was that the further cooperation with the Soviet Union and the "camp" of socialist countries "did not raise a question of changing the course or returning to the 'camp', and so on," because Yugoslavia had already advocated "principled socialist relations and practical international cooperation." The Yugoslav state leadership also believed that "the importance of our socialist practice grew." Such attitudes meant the turn in foreign policy and nearing the attitudes of Moskva. ${ }^{32}$ Such a policy was additionally supported by the poor relations with the West.

The engagement of Yugoslavia in the Balkans most directly contributed to the cooperation and security in Europe. These activities intensified starting from 1959 and were reflected in the efforts of Bulgaria and Romania to turn the Balkans into a "zone of peace", i.e. "nuclear-free zone". It was an attempt of the Eastern Bloc to neutralize the bases with nuclear weapons in the Balkans and the Adriatic region. ${ }^{33}$ The sessions of 1961 in Athens and 1962 in Sofia, showed the ideological bias and split in attitudes of gathered States regarding the issue of security in the Balkans. At the third session of the Committee for Balkan Cooperation, held in Bucharest in late May, the Yugoslav representatives principally accepted the idea of a "nuclear-free zone in the Balkans", but also drew attention to the unreality of the given initiative. In their opinion, it was necessary to build better bilateral relations among the countries in the Balkans. For these reasons, the main objective of Yugoslav diplomacy was "to improve and develop all forms of cooperation among the Balkan countries." This was considered a prerequisite for "improving the atmosphere," gradual advance towards "general consolidation" and improvement of political relations. In their opinion, only a comprehensive development of bilateral relations, Balkan cooperation and trust, could lead to the fulfilment of the idea of "a nuclear-free zone in the Balkans and the Adriatic region," the conclusion of a non-aggression pact and collective security, and reduction of armaments. In Belgrade, it was estimated that any Yugoslav

32 Ibid.

33 Initiative to expand the Balkan cooperation was started by Romania, and very soon supported by Bulgaria. Basic slogans reflecting the efforts of cooperation were "zone of peace" and "nuclear-free zone in the Balkans." DAMSPRS, PA, 1963, f-111, dok. 5, br. 418122, 419793, 442104, 442383, 442432. 
initiative without good bilateral relations between the Balkan countries, was unrealistic, and interpreted as siding with the Eastern bloc. For these reasons, Yugoslavia and the Balkans opted for a policy of active peaceful coexistence. ${ }^{34}$ Such a policy most directly contributed to cooperation and security in the Balkans, and therefore in Europe.

A year later, at the fourth session of the Committee for Balkan Cooperation, held in Belgrade in June 1964, the Yugoslav representatives tried to objectively perceive the world political situation and its impact on the Balkans. They considered it important that the Balkan countries accept the codification of the principles of coexistence and its application in the Balkans. This context covered three basic principles of cooperation, "the consistent application of communication method and peaceful resolution of outstanding issues in the spirit of the principles of active peaceful coexistence, active involvement in all actions aimed at ensuring peace and constructive peaceful cooperation and further improvement and development of good, neighbourly bilateral relations among Balkan countries." Yugoslav representatives generally accepted a notion of "nuclear-free zones" in Europe, including the Balkans, but they also considered that the creation of nuclear-free zone in the Balkans and the Mediterranean was a "very narrow" issue for the capacity of a conference with the participation of representatives of the Balkan countries. The strengthening of the cooperation in the Balkan was considered "as widely as possible" through interconnection, development of cultural relations and strengthening of scientific ties among the Balkan nations. Those views were incorporated into the framework of Yugoslav foreign policy. $^{35}$

A new meeting between Yugoslavia and the Soviet Union took place in the second half of August 1963. ${ }^{36}$ "The Chinese issue" which burdened external and internal position of the Soviet leadership largely

34 DAMSPRS, PA, 1963, f-111, dok. 5, br. 418122, 419793, 442104, 442383, 442432.

35 DAMSPRS, PA, 1964, f-182, dok. 9 i 10, br. 46004, 410664, 415924 i dok. 10, br. 424414.

36 During his visit to Yugoslavia N. S. Khrushchev visited the earthquake-devastated Skopje and Zagreb. AJ, KPR, I -3-a/101-51, Razgovor N. S. Hruščova i predsednika Tita sa rukovodstvom Makedonije, 22. avgust 1963; РГАНИ, Ф. 52, Он. 1, Д. 544, Л. 104-109, Реч Н. С. Хрушчова на ручку у граду Загребу 1. септембар 1963. 
influenced the content of the talks between N. S. Khrushchev and J. B. Tito. These were also influenced by a profound social crisis that made the Soviets talk about the "brilliant" progress, successes in building socialism, the changed appearance of the towns and villages in the USSR. ${ }^{37}$ The aim was to make the Soviet Union more attractive than it really was. In such circumstances, the talks on "European issues" were reduced to the exchange of information, which contained the essence of the policy of Yugoslavia and the Soviet Union. The position of Yugoslav foreign policy in Europe was marked "stable". The relations with the Soviet Union were defined as "good and getting better". When it comes to the United States, Tito noted that Yugoslavia was denied the status of most favoured nation in trade, which meant that relations deteriorated. When it comes to European countries, only relations with Spain and Albania were evaluated as bad, which indirectly led to the conclusion that Yugoslavia did not distinguish between countries with different political or the same systems. Tito noted that the cooperation with France was better than before, as well as that relations with West Germany were not diplomatic, but economic, although reduced by $40 \%$. When it comes to East Germany, he stressed the need and desire of Yugoslavia to improve relations and noted that Belgrade and Berlin were negotiating compensation for the victims of Nazi terror. Relations with the Third World countries Tito defined as consistent. ${ }^{38}$

The last meeting of N. S. Khrushchev and J. B. Tito, which took place in Moscow on June 8, 1964, was not an ordinary annual exchange of views at the highest level of the Soviet Union and Yugoslavia. "Consultations" in which they exchanged information of "sensitive" character, set out precise analyses, evaluated the characters and the ability of political leaders of the Third World countries, defined the political aims and the ways to fulfil them, expressed a high degree of agreement, contained all the elements of a common policy. It was the result of the bonding of Yugoslavia and the Soviet Union, which started in 1962. Topics were the same as in previous meetings, but the talks were much more meaningful and rich. N. S. Khrushchev and J. B. Tito only incidentally mentioned the "European issues" i.e. the relations between the socialist countries, particularly the crisis in relations between the USSR and Romania caused by the fact that the authorities in that country accepted China's position.

37 РГАНИ, Ф. 52, ОН. 1, Д. 544, Л. 5-36, Записник разговора Н. С. Хрушчова и Ј. Б. Тита од 26. августа 1963. године.

38 Ibid. 
Yugoslav assessment was that the Soviet Union liberalized their former views regarding forms of cooperation of socialist countries and parties, but also that the ideological conflict with China urged it to discipline others and impose itself as the indisputable leader of the socialist world. ${ }^{39}$ In such circumstances, Moscow blamed Belgrade for "demonstrating" its non-bloc policy too openly which itself could not have been possible if there were no military blocs and their differences. The dispute was further "deepened" by Yugoslavia insisting on "its special course" in building socialism. Especially because Khrushchev believed that the behaviour of Bucharest was due to the fact that the Romanian leadership followed the example of Yugoslavia and was entering the conflict with the USSR, Czechoslovakia, the German Democratic Republic, and Hungary more and more frequently. N. S. Khrushchev believed that such behaviour was the result of the weakening of tensions between military blocs and the absence of a direct threat of war. ${ }^{40}$ During his visit to Moscow, J. B. Tito emphasized that "both sides started with the recognition of two sovereign German states with different social and political systems." On that occasion, the Soviet Union and Yugoslavia agreed on the unchangeability of existing borders in Europe, not providing the German states with nuclear weapons, further easing of tensions on the European continent including the Balkans, the formation of nuclear-free zone, convening a European conference on security and cooperation. ${ }^{41}$

Frequent meetings between Belgrade and Moscow were part of the initiatives coming from the East whose aim was to stabilize the situation in Europe. The intention of the Soviet Union and Eastern Europe was

39 РГАНИ, Ф. 52, ОН. 1, Д. 595, Л. 85-134, Запись беседы Н. С. Хрущева с И. Б. Тито во время визита И. Б. Тито в Ленинград, 8-9. Июня 1964г; AJ, KPR, I-2/18-2, Zapis razgovora Prvog sekretara CK KPSS i Presedavajućeg Saveta ministara SSSR N. S. Hruščova sa Generalnim sekretarom SKJ i Predsednikom SFRJ J. B. Titom, 8. jun 1964; Југославија-ССС, Сусрети и разговори, 606-640.

40 Ibid.

41 РГАНИ, Ф. 52, Он. 1, Д. 595, Л. 85-134, Запись беседы Н. С. Хрущева с И. Б. Тито во время визита И. Б. Тито в Ленинград, 8-9. Июня 1964г; AJ, KPR, I-2/18-2, Zapis razgovora Prvog sekretara CK KPSS i Presedavajućeg Saveta ministara SSSR N. S. Hruščova sa Generalnim sekretarom SKJ i Predsednikom SFRJ J. B. Titom, 8. jun 1964. godine; DAMSPRS, DA, PA, f-154, dok. 2, br. 46194, Naše izjave u vezi problema evropske bezbednosti. 
to resolve the "German issue" in a peaceful manner and with the conclusion of a peace treaty that would sanction the existence of two German states, establish a special status of West Berlin, and leave the question of German reunification to Bon and Berlin. According to the estimates of Yugoslav diplomats, the main goal of the USSR was to prevent future aggression of Germany. For Moscow, the establishment of European security system was essentially linked to the German issue. In the initiatives coming from Warsaw, Prague, Bucharest, and Berlin, Yugoslav diplomacy saw the tendency of the arming of the Federal Republic of Germany, isolated US policy - the Federal Republic of Germany in Europe, stopped the formation of multilateral NATO forces in the Old World, "frozen" the proliferation of nuclear weapons, made decisive steps towards improving the international situation in accordance with the principles of the UN, improved neighbourly relations, improved economic and cultural cooperation, preserved the existing borders... ${ }^{42}$ Such efforts were contrary to the European policy of the US and attempts to use the "common policy" of the West for creating the impression of the cessation of American hegemony in NATO, indirectly enabling the nuclear arming of Germany, and putting all nuclear facilities of Western European countries under the unique American control. ${ }^{43}$

Yugoslavia also made a statement regarding these issues. In a statement issued on the occasion of the Polish Memorandum on nuclear armaments freeze in Europe (so-called "Gomulka plan"), in addition to unconditional support, it was stressed that this should be the initial and transitional measure, aimed at stopping the nuclear arms race and consolidating security and trust among the countries of Central Europe. ${ }^{44}$

In the late June and early July 1964, Tito visited Poland. During the talks, one of the main issues was the cooperation and security in Europe. Both sides emphasized the importance of a "program of general and complete disarmament," which was proposed in Moscow. In this context, they also supported initiatives "that led to the limitation of arming and

42 DAMSPRS, DA, PA, 1966, f-154, dok. 2, br. 46194, Problemi evropske bezbednosti i inicijative istočnoevropskih zemalja.

43 Radovan Vukadinović, Sila i interesi: Vanjska politika SAD, (Zagreb: Centar za kulturnu djelatnost omladine, 1972), 273; Čehulić Vukadinović, Euroatlantizam i suvremeni međunarodni odnosi, 71, 72; Vukadinović, Čehulić Vukadinović, Božinović, NATO euroatlanska integracija, 114-126.

44 Љубодраг Димић, „Југославија и 'План Гомулка', реферат поднет на Међународној научној конференцији Југословенско-пољски односи у XX веку, Београд 29-30. септембар 2016, (рад у штампи). 
easing tensions in particularly irregular regions." One of such initiatives was to establish "nuclear-free zone in Central Europe and the Balkans, as well as in other parts of the world." Yugoslavia also supported the Polish initiative regarding "nuclear and thermonuclear armament freeze in Central Europe," believing that it could encourage further steps in disarmament and easing of tensions in the area of crucial importance for European security. Tito and his collocutors marked the "German issue" a key to security in Europe. They were consistent in the view that the policy conducted by DR Germany contributed to peace. In contrast, the views of the Federal Republic of Germany were estimated as militaristic, revanchist, revisionist, and the support that the West provided to such a policy destructive for security in Europe. The stability of the European continent depended on: accepting the reality of the existence of two German states, recognition of the unchangeability of existing German and Polish borders, renunciation of nuclear weapons on the territory of two German states, and the signing of a peace treaty with the two German states. $^{45}$

Just a few days after Tito's visit to Poland and the presentation of two almost identical views on key issues of European security and cooperation, the delegation of the Yugoslav League for Peace at the conference of the representatives of peace movements of Mediterranean countries, held in Algiers from July 5 to 9, 1964, promoted denuclearisation of the Mediterranean. On that occasion, they adopted documents which requested the removal of all nuclear weapons from Mediterranean, elimination of military bases, suspension and prohibition of production, distribution and import of nuclear assets. One of the proposals of the Yugoslav delegation for the governments of the riparian Mediterranean countries was to begin denuclearization themselves, appeal to the great powers to withdraw their nuclear weapons, close the bases and suspend the nuclear arms race. ${ }^{46}$

45 AJ, KPR (837), I-2/20, Poseta J. B. Tita Poljskoj od 21. 6. do 2. 7. 1964; Dragan Bogetić, „Razgovori Tita i Gomulke u Varšavi 1964. i u Beogradu 1965. godine. Sličnosti i razlike u jugoslovenskim i poljskim stavovima o međunarodnim odnosima i o odnosima između socijalističkih zemalja“, Jugoslovensko-poljski odnosi u XX veku, urednici prof. dr Momčilo Pavlović, dr hab. Andrzej Zaćminski, dr Dragomir Bondžić, (Beograd: Institut za savremenu istoriju, 2015), 323-342.

46 DAMSPRS, PA, 1964, f-242, dok. 9, br. 416670, 428910, 431753; Ђ. Васиљевић, „Југословенски ставови о европском питању“, Материјали о европској безбедности и сарадњи, (Београд, 1969), 162. 
During his visit to Czechoslovakia in early June 1965, Josip Broz and Antonin Novotny noted "the unity of views" on major international issues. They urged the Government to "strengthen the security and peace" in Europe, condemned the militarization of the Federal Republic of Germany and the efforts to annul the results of the Second World War. They were worried about Bon's efforts to gain access to atomic weapons and ignoring the existence of DR Germany by the Western states. In a joint statement, Tito and Novotny once again emphasized the importance of strengthening security in Europe, condemned the revival of the militarist and revanchist tendencies, requested recognition of the two German states and the normalization of the situation in Berlin, stood up for the convening of the Conference on Security and Cooperation in Europe. ${ }^{47}$

The solving of "German issue" and European security were discussed in June 1965 and during Tito's visit to the German Democratic Republic. On that occasion, Josip Broz and Walter Ulbricht expressed almost the "exact match" of the two countries' positions on key international issues. They agreed upon the growing influence of socialism, strengthening of the forces committed to peace, increasingly important role of non-aligned countries, and increasingly aggressive policy of the US and the West. When it comes to European issues, Tito and Ulbricht were of the opinion "that certain efforts and measures had to be taken to permanently guarantee European security and peaceful development of the peoples of Europe." These "efforts" and "measures" included the easing of international tensions, negotiations of European countries on disarmament, elimination of the "elements of the Cold War" in Europe, creating nuclear-free zones... Considering the political situation in FR Germany, they spotted the strengthening of militarist and revanchist forces, their attempts to revise the results of World War II, change the existing borders, and get their hands on nuclear weapons. Tito and Ulbricht agreed that peace and security in Europe could only occur with respect to the reality of the existence of two German states with different social and political system, respect for the existing balance of power, stopping the arms race, the ban on the deployment of nuclear weapons on the territory of the Federal Republic of Germany, normalizing the situation in Berlin, stop ignoring and isolating DR Germany. In this context, the two

47 AJ, KPR (837), I-2 /26-2, Poseta J. B. Tita DR Čehoslovačkoj, 2-8. jun 1965; DAMSPRS, PA, f-154, dok. 2, br. 46194, Naše izjave u vezi problema evropske bezbednosti. 
statesmen have called for the convening of the conference of European states on security in Europe. ${ }^{48}$

All estimations regarding developments and ways to establish cooperation and security in Europe made in Prague and Berlin were repeated during Tito's visit to the Soviet Union in June and July 1965. Leonid Brezhnev and Tito estimated that Europe was not ready to embark on an adventure in Algeria caused by the change of Ben Bella. They were of the opinion that NATO was losing the power, suffering divisions and probably would not survive 1969 and signing of a new agreement with the members. In this context, the Soviets were willing to support France and Norway in their dissatisfaction with the policy of the NATO pact. In a joint statement, Tito and Brezhnev expressed the need for the formation of "a reliable system of European security and the peaceful resolution of the German issue - starting with the fact that there were two German states with different social systems." 49

When it comes to the assessment of the situation in Europe and ensuring security, the talks were conducted with representatives of the Polish party-governmental delegation headed by Vladislav Gomulka in Belgrade in November 1965. However, on this occasion, they noted a certain deviation from the "closeness of views" established in Prague, Berlin and Moscow. The differences were visible around the "tactical approaches to and assessments of" certain issues and were a sign that the Yugoslav foreign policy began with mild deviation, when European issues were concerned, in relation to the view in unison with the countries of the socialist bloc, typical for the whole 1965. The Yugoslav side identified European security as a "major concern" of the Polish state. They talked about the German revanchism regarding the issue of borders and nuclear weapons. The Yugoslav side supported the idea of nuclear-free zone in Europe, but, at the same time, drew attention to the "positive trends," reflected in a larger number of contacts, expanded cooperation, and a European policy of France. Joint statement once again highlighted the need to guarantee the immutability of the German and Polish borders. Yugoslavia also supported the Polish initiative on the creation of nuclear-free zone and the freezing of nuclear weapons in Central Europe. This was

48 AJ, KPR (837), I-2/26-2, Poseta J. B. Tita DR Nemačkoj, 8-13. jun 1965; DAMSPRS, PA, f-154, dok. 2, br. 46194, Naše izjave u vezi problema evropske bezbednosti.

49 АJ, KPR, I-2 /26-3, Разговори Л. И. Брежњева и Ј. Б. Тита у Москви 19. и 29. 6. 1965; Васиљевић, „Југословенски ставови о европском питању“, 164. 
once again followed by the proposal for the convening of a conference on European security. ${ }^{50}$

The range of Yugoslav activities in Europe was somewhat restricted by reserved attitude of European countries towards its nonaligned policy (anti-colonialism, anti-block policy, opposition to spreading nuclear weapons, and support for developing countries...). For these reasons, Belgrade sought to improve bilateral relations, primarily with neighbouring countries, and then with most European countries. This could explain why at the beginning of the 1960s Yugoslavia did not promote its own initiatives and proposals. Priority was given to practical cooperation with the countries of both blocs. Along with that, according to estimates, Yugoslavia supported all initiatives that led to easing tensions, increasing security, and developing cooperation among the European countries. This was not contrary to the attitudes of national leadership that the proposals were not realistic enough and therefore could not give visible results. In such circumstances, Belgrade knew it had to "adjust" its policy to the current situation in Europe and the growing need for "wider cooperation and peaceful coexistence", overcoming closed economic markets, removing economic and trade barriers, the greater circulation of ideas and people, and ensuring security. These issues were very important and had to find their place in Yugoslav foreign policy as soon as possible. This meant providing stronger support to initiatives advocating a wider cooperation among the European countries and the region. When it comes to initiatives that had a block or ideological character, the state leadership was of the opinion that such meetings should be avoided. In addition to developing cooperation with neighbours, it was also necessary to improve relations with "major partners" (socialist countries: the USSR, Romania, Czechoslovakia, Hungary, and western countries: France, Scandinavia and the Benelux countries). They aimed to intensify consultations on all current European issues and establish

50 AJ, KPR (837), IX, 101/I-161, Informacija o poseti poljske partijsko-vladine delegacije SFRJ 15-19. 11. 1965; Bogetić, „Razgovori Tita i Gomulke“, 323-342. 
a closer relationship with the representatives of European parliaments, socio-political organizations, and parties..$^{51}$

Yugoslav involvement in the field of security in Europe once again came to forefront in December 1965 at the $20^{\text {th }}$ session of the UN General Assembly. On that occasion, Resolution no. 2129 was adopted unanimously. Yugoslavia was one of the promoters of the "Actions on the regional level with a view to improving good neighbourly relations among European States having different social and political systems." The resolution was passed at a time of crisis in international relations. The US increased their military presence in Vietnam and expanded the range of military operations. The conflict between India and Pakistan threatened to engage China. The United States continued to pressure South American countries (Brazil, Bolivia, and the Dominican Republic). The declaration of independence of Southern Rhodesia produced instability in Africa and revived the activities of former colonial powers. The relations between Washington and Moscow were tensed. The interests of the great powers have greatly paralyzed the activities of the United Nations. In such circumstances, Yugoslav support to Resolution no. 2129 was a support to UN reaffirmation. The document emphasized the need to respect the equal rights and mutual interests of European countries, prompted an increase in their political, economic, scientific-technical and cultural cooperation, appealed to the governments of European countries to "increase efforts" to improve mutual relations in order to create an atmosphere of trust and resolve issues that hinder the easing of tensions in the world. ${ }^{52}$ At the session held on the occasion of the adoption of Resolution no. 2129 Yugoslav ambassador to the UN Danilo Lekić emphasized the commitment of Yugoslavia to strengthening international understanding and comprehensive development of friendly relations in the world. Noting that in the past there were obstacles on the way of establishing and deepening relationships "with countries in the European region," Lekić said that in recent years "certain steps were taken to improve good neighbourly relations between European countries with different political systems." Such cooperation, according to him, was the result of the willingness of European countries to cooperate with Yugo-

51 DAMSPRS, PA, 1966, f-154, dok. 2, br. 46194, Odnosi Jugoslavije sa evropskim zemljama i njena pozicija u Evropi.

52 The resolution was submitted by Romania. Aide Memoire o unapređenju saradnje evropskih zemalja, publikacija DSIP-a, (Beograd, 9. januar 1967); Васиљевић, „Југословенски ставови о европском питању“, 163. 
slavia on the principles of full equality of respect, independence, sovereignty, territorial integrity, non-interference in internal affairs, and these were the basic principles of active and peaceful policy advocated by Yugoslav diplomacy. He thought it was particularly important because resolution referred to Europe, an area where "different socio-political systems were most distinctive and most directly expressed" and where the barriers artificially imposed by the Cold War should disappear as soon as possible. Resolution no. 2129 greatly contributed to the stabilization of peace in Europe, and Yugoslav diplomacy considered it the most effective contribution to the peace in the world. ${ }^{53}$

Yugoslav diplomacy continued to promote these attitudes through intensive cooperation and relations with the countries, sponsors of the Resolution no. 2129. A number of meetings were organized in New York to exchange opinions on how to implement the resolution in the fields of politics, economy, culture, education, science and technology. At these meetings, Yugoslavia represented the view that political developments in Europe imposed an obligation of "viable and realistic" approach to solving the problems of security and cooperation. To this end, Yugoslavia developed a special Aide memoire. It restored the support to Resolution no. 2129, represented situation in Europe and defined the possible principles of cooperation. It also pointed to the capabilities of existing organizations to establish cooperation among European states and indicated possible forms of political, economic and cultural cooperation. Particularly intensive cooperation and exchange of views was established with Austria and Romania. ${ }^{54}$

In an expose submitted to the Federal Council of the National Assembly of the SFRY in January 1966, the State Secretary for Foreign Affairs Marko Nikezić recalled that the basis of Yugoslavia's foreign policy was an active peaceful coexistence. It implied commitment "to the right of each nation to free and independent choice of development and social system without outside interference, respect for sovereignty and territorial integrity of all states, the renunciation of the use of force in international relations and the settlement of disputes by peaceful means, as well as equal political and economic international cooperation." When it comes to Europe, he noted that situation on the continent was "relatively calm" over the past year. He also assessed that the relations between so-

53 DAMSPRS, PA, 1965, f-182, Govor D. Lekića od 18. 12. 1965; DAMSPRS, PA, 1965, f-182, dok. 7, br. 444178.

54 DAMSPRS, PA, 1966, f-154, dok. 2, br. 442150. 
cialist and Western countries improved, trade expanded, and the number of peace initiatives increased. In his opinion, Yugoslavia gave a significant contribution to a realistic approach to the issue of European security and cooperation which implied the acceptance of the fact that there were two German states in Europe. Presenting the views of Yugoslav diplomacy Nikezić particularly emphasized that the unification of Germany was "the question of German people" but that such Germany must be "a factor of peace and stability in Europe." Military spirit of revanchism and plans that would allow FR Germany access to atomic weapons Yugoslavia considered "dangerous and unacceptable" and strongly opposed them because they were contrary to the interest of European nations, and German people. ${ }^{55}$

During 1966, Yugoslavia did not significantly change its attitude towards European security. Its diplomatic representatives, affirming the recommendations of the United Nations, at the session of Inter-Parliamentary Union held in Canberra in mid-April 1966, gave the initiative for holding a conference, aimed at expanding cooperation and bringing closer the countries with different social systems. The aim was to create conditions under which, one day, the European countries would be able to solve the problems they face. Yugoslav initiative was adopted unanimously. ${ }^{56}$

The performance of Yugoslavia in Canberra was a part of diplomatic campaign whose aim was to support the idea of European Security and Cooperation presented in Resolution no. 2129 unanimously adopted at the $20^{\text {th }}$ session of the UN General Assembly. ${ }^{57}$ Yugoslav initiative was met with resistance based primarily on distrust of the West that it was a part of Moscow's plans for convening the Pan-European Conference that would deal with the issue of European security. However, the Yugoslav initiative was supported by the participants of the round table East-West, held in Paris in April 1966. ${ }^{58}$

In the second half of April 1966, during Tito's visit to Romania, hosts and guests both observed "increased aggressive activity of imperialist forces." They thought it was a historic attempt to slow down the process of "progressive and democratic development." When it comes

55 Стенографске белешке Савезне скупштине, Савезно веће, 39. седница од 20. јануара 1966. године, (Београд, 1966), 123-124.

56 Васиљевић, „Југословенски ставови о европском питању“, 164.

57 DAMSPRS, PA, 1966, f-157, dok. 7, br. 410614.

58 DAMSPRS, PA, 1966, f-157, dok. 7, br. 416942. 
to Europe, both parties supported the views on cooperation, trust, and good neighbourly relations between the countries of Europe outlined in UN Resolution no. 2129. In this context, both sides agreed to establish an effective system of European security, and objected to the approach of "the West German militarism to the nuclear weapons in any form." They thought that improving relations among the Balkan states was very important and demonstrated commitment to the promotion of cooperation in the future. ${ }^{59}$

The meeting of representatives of parliaments of nine European countries, supporters of the resolution "Actions on the regional level with a view to improving good neighbourly relations among European States having different social and political systems" was held at the invitation of the Federal Assembly of Yugoslavia in September 1966. The meeting was carefully prepared in the spring 1966 and UN Secretary General U Thant was informed about the entire procedure. Preparations for the meeting included prominent Yugoslav diplomats whose suggestions on the development of economic relations between East and West, the conclusion of the multilateral agreements of the European countries on economic cooperation, planning of regional cooperation, promotion of scientific-technical cooperation, formation of a common European system of energy supply, increased industrial cooperation and inter-regional circulation of capital, creating an atmosphere for a faster resolution of political issues were discussed before the conference. Representatives of the Western states, sponsors of the Resolution no. 2129 held that meeting in Belgrade might be for information purposes only and without making any decisions. Representatives of the United Kingdom and the United States did not approve of the gathering in Belgrade. Gaullists in French Parliament supported the meeting in Belgrade, believing that it could bring "a quality change in relations in Europe."60

At the conference, the President of the Federal Assembly of the FPRY Edvard Kardelj came forward with the proposal of holding a consultative meeting of representatives of European parliaments, whose task would be to "bridge" the obstacles and differences "in the field of international relations and cooperation among European peoples." Kardelj believed that cooperation between European parliaments can be a significant factor in providing trust, communication and security in Europe. Representatives of the Western states shared a common view that the

59 AJ, KPR (837), I-2/28, Poseta J. B. Tita Rumuniji, 18-23. 4. 1966.

60 DAMSPRS, PA, 1966, f-157, dok. 7, br. 432220, 433815, 434129, 434215. 
future meeting should be held within the framework of the Inter-Parliamentary Union. There were those who felt that the meeting in Belgrade was sufficient and did not see the need for another gathering. However, in the end, the Yugoslav proposal was unanimously accepted. ${ }^{61}$

A further step in implementation of the recommendations of Resolution no. 2129 and realization of Yugoslav initiative on the organization of consultative meeting of the representatives of European parliaments, was the meeting of foreign ministers of "Nine" held in New York in October 1966. Since the Yugoslav proposal was unanimously accepted, and the Federal Assembly of Yugoslavia supported the idea of convening the conference of the members of European parliaments, E. Kardelj sent a letter to the presidents of European parliaments on December 14, 1966. It conveyed the belief of the Yugoslav side that a conference of representatives of European parliaments would make a significant contribution to the strengthening of a mutual trust in Europe, bringing the countries closer together, and freeing Europe from "the phenomenon and the result of the Cold War." 62

In early January 1967, in Aide memoire on the improvement of cooperation between European countries, the Ministry of Foreign Affairs of Yugoslavia expressed its willingness to contribute to a favourable development in Europe "within the limits of real opportunities." Yugoslav diplomats believed that the pending process of improving relations and cooperation in Europe was in accordance with the interests of all European countries regardless of their social and political system. They assumed that, for these reasons, European countries were trying to come up with "possibilities and ways" to improve security and cooperation in Europe. In such circumstances, Yugoslavia made it clear that other European countries "did not conceive the future of Europe in the framework of bloc and other forms of division," but in "all-round cooperation between independent and equal states." For Yugoslavia, the only possible policy that could have provided security and cooperation in Europe, was one based on the principles of active peaceful coexistence. In the opin-

61 Beside Yugoslavia, also invited were representatives of Sweden, Romania, Austria, Belgium, Finland, Bulgaria, Denmark, and Hungary. Representatives of Austria did not attend the meeting in Belgrade.

DAMSPRS, PA, 1966, f-157, dok. 7, br. 414722, 416942, 410614, 420616, 424936, 414759, 432220, 433815, 434129, 434215.

62 DAMSPRS, PA, 1966, f-157, dok. 7, br. 444460; Stenografske beleške Narodne skupštine, Savezno veće, 48. sednica od 24. i 25. novembra 1966, (Beograd, 1966), 5152; Васиљевић, „Југословенски ставови о европском питању“, 164-167. 
ion of Belgrade, mutual cooperation of European countries would enable them to fulfil another obligation - to provide more effective assistance to developing countries. ${ }^{63}$

"Shifts among the forces", tendencies to change the inherited relations between power and influence, complex and controversial development of contemporary international relations, were some of the characteristics of the times when the issue of European security was reopened. In such circumstances, the "European area" and "the direction of its development," became all the more significant for Yugoslavia. Accordingly, the Yugoslav foreign policy started adapting to new circumstances, and Yugoslav diplomacy turning to Europe. Yugoslav perspective of Europe made an important part of the exposé submitted by the Secretary of State for Foreign Affairs Marko Nikezić to the delegates of the Federal Council of the Federal Assembly of Yugoslavia in January 1967. ${ }^{64}$ Exposé confirmed that the Yugoslav diplomacy, regardless of its involvement in the Third World, did not lose track of the situation in Europe and very early noticed causal relations by which each confrontation of the great powers in Europe, most directly threatened the world peace, just as the easing of tensions on this continent contributed to the strengthening of peace in the world. For these reasons, Belgrade believed that "favourable evolution of the situation in Europe, particularly in the field of relations between East and West," indicated a real progress "on the way to peaceful international cooperation." Earlier bloc confrontations and the policy of force derived therefrom experienced significant modifications and were gradually abandoned as a frame of foreign policy in most European countries. Such developments were considered favourable for new political initiatives and conscious action which was to move a historical process in a desired direction. Belgrade was not ready to miss such an opportunity. All the more so because there was a belief that the current stability was not the result of nuclear powers' interest in confrontations, more autonomous operation, increased roles and specific national interests of European states to cooperate, develop rapidly and take care of

63 Aide Memoire o unapređenju saradnje evropskih zemalja.

64 Stenografske beleške Savezne skupštine SFRJ, Savezno veće, 51. sednica od 26.i 27. januara 1967. godine, (Beograd, 1967), 7-15. 
security in Europe. Under the given circumstances, the military blocs in Belgrade were forced to "adapt to new trends," which in the future would lead to their destruction. European countries were convinced that a bloc division "was not inevitable in the future Europe" and that national security could be protected more effectively by equal cooperation among the states rather than relying on the great powers and their military potential. Yugoslav diplomacy supposed that the possibilities of Europe, after the Cold War and divisions, would increase in the future, and that this should be taken into account. Such a development is considered good for the peoples of Europe, and the Mediterranean countries, Africa and Asia, towards which Europe had responsibility, especially in the field of eliminating colonialism and underdevelopment. Therefore, Yugoslav diplomacy opted for launching initiatives that would, as an alternative to "armed peace" imposed by military blocs, enable a broad dialogue on European issues, encourage joint action of European states to ensure security, provide unhindered independent development of each and every European country. Such initiatives included the support to the UN Resolution no. 2129, the efforts to convene meeting of representatives of parliaments across Europe to discuss security, and insisting on bilateral cooperation between European countries. The Yugoslav commitment to the organization of the Conference on Security and Cooperation should be also mentioned. ${ }^{65}$

In the second half of the 1960s there were other initiatives for holding of the conference on security. One of these initiatives, which Yugoslavia did not support, was the holding of a conference of communist parties on the theme of collective security in Europe. The initiator of this idea, which began in 1965, and gained full momentum and the support of the USSR and the Warsaw Pact in 1966, was the Communist Party of France. Yugoslavia thought it "needed to stay away from all the initiatives that even bore semblance of unilateral and concerted action with the parties of socialist countries." In this way, it demonstrated "an independent international position in the world, especially in relation to the blocs in

65 Ibid. 
Europe". ${ }^{66}$ De Gaulle's withdrawal from NATO, the imminent termination of NATO agreement and uncertainty of its extension, the increasing interest of the USSR in European issues, the opportunity to perform activation of the movement for peace in European countries, grouping of forces opposed to increasing the danger of war, demonstration of the unity of the communist parties of Europe were some of the motives for the convening of the Conference of European Communist and Workers' Parties devoted to European security. The conference was held in Karlovy Vary.

Yugoslavia considered that this type of counselling "narrowed the base" for achieving the desired results, whereas Josip Broz Tito pointed out that the attitudes of Yugoslavia differed in terms of "the way of looking at current trends in Europe and assessment of the European situation as a whole." There were some facts of particular concern: neglecting positive elements of European trends and changes in the socio-economic structures "leading to qualitatively new relations in Europe"; bypassing the policy of non-alignment as "a major factor in the fight for the stabilization of the international situation and the peace in the world"; neglecting complex problems of developing countries and provoking instability in the world. The Conference condemned the US policy in Europe and marked it as a main impediment to the cooperation between European countries. It pointed out that European problems should be solved without involvement of the US. The policy of the Federal Republic of Germany was marked as the main obstacle to the peace in Europe whereas the policy of the German Democratic Republic was supported. The emphasis was put to the role of European communist parties in the struggle for peace and security in Europe and establishing cooperation with other political parties that had the same goal (especially the Social Democrats, trade unions and certain Catholic circles). There were claims for the recognition of two German states and existing borders, as well as for the ban of nuclear weapons to FR Germany. The removal of artificial barriers between the socialist and communist countries was marked as the imperative of security in Europe. There was also a call for withdrawal of foreign troops and the liquidation of foreign military bases on the territory of

66 AJ, CK SKJ, IX, 144/LVI-3, Zabeleška o inicijativi KP Francuske za sazivanje evropske konferencije komunističkih partija o pitanju evropske bezbednosti, 21. 2. 1966; AJ, CK SKJ, IX, 144/LVI-4, Inicijativa evropskih komunističkih partija za saziv Konferencije o evropskoj bezbednosti, 23. 5. 1966; AJ, CK SKJ, IX, 144/LVI-9, Informacija o zvaničnom sondiranju učešća delegacije SKJ na konferenciji evropskih komunističkih partija o pitanjima evropske bezbednosti, 12. 7.1966. 
Europe. The formation of Europe without military blocs was suggested. There was an initiative for holding of the conference of European states on the issue of security. The support was given to the principle of neutrality and the prominent role of neutral countries in dealing with European issues. There were also the requests for the liquidation of foreign troops and foreign military bases. The attention was drawn to "favourable circumstances" that in 1969, the NATO agreement would expire; the creation of a Europe without military blocs was proposed. ${ }^{67}$

The analysis of the present circumstances made by the Yugoslav state and party leadership showed that the conference in Karlovy Vary (April 1967), as well as counselling in Warsaw that preceded it (February 1967) aimed to firmly connect and instruct the Communist Party to contribute to "the strengthening of camp cohesion," enable long-term hegemony of the CPSU in the international communist movement, slow down the processes of evolution and independence of the leaderships of the communist party in socialist countries, prevent direct connections between the socialist and capitalist countries in Europe, and strengthen the international position of the USSR as a great power compared to the US and China. ${ }^{68}$

In the late 1967, Minister Nikezić presented the circumstances in Europe to the representatives of the Federal and Organizational Council of the Federal Assembly of the SFRY. The main message of this presentation was that Yugoslavia would stay engaged at the international level, but that "tasks of foreign policy must evolve" in line with the development of internal and international circumstances. "Reforms", as he called the moment of socio-economic development of the country, offered various forms of connecting with the world. When it comes to Europe, Yugoslavia supported the tendency of "expansion of cooperation" between European countries, but its diplomacy was aware of the extent to which the conflict in the Middle East (Arab-Israeli war of 1967), events in Greece (Seduction military dictatorship) or Cyprus crisis, instigated new

67 AJ, CK SKJ, IX, 144/LVI-9, Informacija o zvaničnom sondiranju učešća delegacije SKJ na konferenciji evropskih komunističkih partija o pitanjima evropske bezbednosti, 12. 7. 1966; AJ, CK SKJ, IX, 144/LVI-11, Predlog odluke o neučestvovanju predstavnika SKJ na Konferenciji evropskih komunističkih partija o evropskoj bezbednosti; AJ, CK SKJ, IX, 144/LVI-26, Izlaganje J. B. Tita na sednici Predsedništva CK SKJ od 16. 3. 1967; AJ, CK SKJ, IX, 144/LVI-37, Pismo CK SKJ upućeno CK KP ČSSR od 18. 4. 1967; AJ, CK SKJ, IX, 144/LVI-46, Informacija o Konferenciji KP Evrope u Karlovim Varima, 12. 5. 1967; AJ, CK SKJ, IX, 144/LVI-51, Rezolucija Konferencije u Karlovim Varima. Ibid. 
disagreements and made European situation seem unfavourable. These events led to the knowledge, very important for the Yugoslav diplomacy, that Europe and the Mediterranean were linked to the extent that they could not be separated and that it was illusory to believe that it was possible to achieve security in one of these areas, and have a crisis, conflict and war in another. In such circumstances, Belgrade believed that European countries should be oriented towards a long-term cooperation and "new relationships", regardless of the different social systems, in order to reduce the "external influences" that encourage conflicts and threaten the security. In contrast to divisions, Yugoslav diplomacy saw Europe as a "community of independent and equal states." This goal was to be fulfilled through bilateral cooperation with European countries, initiatives within the framework of foreign policy, and willingness to help in overcoming crisis situations. ${ }^{69}$

The amount of attention devoted to Europe and European issues by the President, the government, and parliamentary bodies undoubtedly showed that the second half of the 1960s shaped "European policy of Yugoslavia."

\section{Sources and Literature}

\section{Sources}

- Diplomatic Archives of the Ministry of Foreign Affairs of the Republic of Serbia (Diplomatski arhiv Ministarstva spoljnih poslova Republike Srbije - DAMSPRS). Political Archives (Politička arhiva - PA).

- Archives of Yugoslavia (Arhiv Jugoslavije - AJ):

- Office of the President of the Republic (Kabinet predednika republike - KPR)

- Central Committee, The League of Communists of Yugoslavia (Centralni komitet Saveza komunista Jugoslavije - CK SKJ)

- The Russian State Archive of Contemporary History - РГАНИ:

- Ф. 52. Он. 1. Д. 595. Л. 1-20

- Ф. 52. Он. 1. Д. 544. Л. 104-109

69 Стенографске белешке Савезне скупштине СФРЈ, Савезно веће, Веће народа и Организационо-политичко веће, 11. седница од 26. и 27. јануара 1967. године, (Београд, 1967), 63-64. 
- Ф. 52. Он. 1. Д. 544. Л. 5-36

- Ф. 52. Он. 1. Д. 595. Л. 85-134

Published sources

- Aide Memoire o unapređenju saradnje evropskih zemalja, publikacija DSIP-a. Beograd, 9. januar 1967.

- Balkanski pakt, Zbornik dokumenata, priredili M. Terzić, M. Basara, D. Tasić et al. Beograd: Vojnoistorijski institut, 2005.

- Четрнаеста седнища ЦК СК Србије. Београд, 1968.

- Југославија и СССР. Сусрети и разговори на највишем нивоу руководилаца Југославије и СССР 1946-1964, приредили Љ. Димић, М. Милошевић, А. С. Стикалин и др. Београд: Архив Југославије, 2015.

- Југославија и СССР. Сусрети и разговори на највишем нивоу руководилаца Југославије и СССР 1964-1980, приредили Љ. Димић, А. Животић, А. Аникејев и др. Београд: Архив Југославије, 2016.

- Југословенско-совјетски односи 1945-1956, Зборник докумената, приредили Љ. Димић, М. Милошевић, Ђ. Борозан. Београд: Министарство спољних послова, 2010.

- Petranović, Branko i Momčilo Zečević. Jugoslovenski federalizam. Ideje $i$ stvarnost, II. Beograd: Prosveta, 1987.

- Почетак краја СФРЈ. Стенограми и други пратећи документи проширене седнице Извршног комитета ЦК СКЈ одржане од 14. до 16. марта 1962. Београд: Архив Југославије, 1998.

- VII конгрес СКJ. Београд, 1964.

- Стенографске белешке Савезне скупштине, Савезно веће, 39. седница од 20. јануара 1966. године. Београд, 1966.

- Stenografske beleške Narodne skupštine, Savezno veće, 48. sednica od 24. i 25. novembra 1966. Beograd, 1966.

- Stenografske beleške Savezne skupštine SFRJ, Savezno veće, 51. sednica od 26. i 27. januara 1967. godine. Beograd, 1967.

- Стенографске белешке Савезне скупштине СФРЈ, Савезно веће, Веће народа и Организационо-политичко веће, 11. седница од 26. и 27. јануара 1967. године. Београд, 1967.

- Четврта седница ЦК СКЈ. Београд: Архив Југославије, 1999.

\section{Literature}

- Aćimović, Ljubivoje. Problemi bezbednosti i saradnje u Evropi. Beograd: Institut za međunarodnu politiku i privredu, 1978. 
- Balkanski pakt, Zbornik radova, ur. Nemanja Milošević. Beograd: Institut za strategijska istraživanja, 2009.

- Bekić, Darko. Jugoslavija u hladnom ratu (Odnosi s velikim silama 19481955). Zagreb: Globus, 1988.

- Bilandžić, Dušan. Hrvatska moderna povjest. Zagreb: Golden marketing, 1999.

- Boffa, Giuseppe. Povijest Sovjetskog Saveza. Od domovinskog rata do položaja druge velesile. Staljin i Hruščov, II. Opatija: Otokar Keršovani, 1985.

- Bogetić, Dragan. Jugoslavija i Zapad 1952-1955. Beograd: Službeni list SRJ, 2000.

- Bogetić, Dragan. „Razgovori Tita i Gomulke u Varšavi 1964. i u Beogradu 1965. godine. Sličnosti i razlike u jugoslovenskim i poljskim stavovima o međunarodnim odnosima i o odnosima između socijalističkih zemalja“. Jugoslovensko-poljski odnosi u XX veku, urednici prof. dr Momčilo Pavlović, dr hab. Andrzej Zaćminski, dr Dragomir Bondžić, 323-342. Beograd: Institut za savremenu istoriju, 2015.

- Bogetić, Dragan. Nova strategija spoljne politike Jugoslavije 1956-1961. Beograd: Institut za savremenu istoriju, 2006.

- Bogetić, Dragan. Koreni jugoslovenskog opredeljenja za nesvrstanost. Beograd: Institut za savremenu istoriju, 1981.

- Богетић, Драган и Љубодраг Димић. Београдска конференција несврстаних земаља (1-6. септембар 1961). Београд: Завод за уџбенике, 2013.

- Bogetić, Oliverai Dragan Bogetić. Nastanakirazvojpokreta nesvrstanosti. Beograd: Export Press, 1981.

- Čehulić Vukadinović, Lidija. Euroatlantizam i suvremeni međunarodni odnosi. Zagreb: Politička kultura, 2010.

- Димић, Љубодраг. Историја српске државности. Србија у Југославијu, III. Нови Сад: Српска академија наука и уметности (огранак у Новом Саду), „Беседа“, издавачка установа православне епархије Бачке и Друштво историчара јужнобачког и сремског округа, 2011.

- Dimić, Ljubodrag. Jugoslavija i hladni rat, Ogledi o spoljnoj politici Josipa Broza Tita. Beograd: Arhipelag, 2014.

- Димић, Љубодраг. „Југославија и 'План Гомулка'“, реферат поднет на Међународној научној конференцији Југословенско-пољски односи у XX веку. Београд, 29-30. септембар 2016, (рад у штампи).

- Гедис, Џон Л. Хладни рат. Ми данас знамо. Београд: Clio, 2003. 
- Geler, Mihail i Aleksandar Nekrič. Utopija na vlasti. Istorija Sovjetskog Saveza. Podgorica: CID, 2000.

- Gray, William Glenn. Germany's Cold War. The Global Campaign to Isolate East Germany 1949-1969. Chapel Hill - London: UNC Press, 2003.

- Kisindžer, Henri. Diplomatija, 1-2. Beograd: Verzal press, 1999.

- Лакер, Волтер. Историја Европе 1945-1992. Београд: Clio, 1999.

- Lis, Lorejn. Održavanje Tita na površini. Sjedinjene države, Jugoslavija $i$ hladni rat. Beograd: BMG, 2003.

- Mastny, Vojtech. „Soviet foreign policy 1953-1962“. Cambridge History of the Cold War, 312-333. Cambridge, 2010.

- Materijali o evropskoj bezbednosti i saradnji, publikacija DSIP-a. Beograd, 1969.

- Mates, Leo. Nesvrstanost. Teorija i savremena praksa. Beograd: Institut za međunarodnu politiku i privredu, 1970.

- Mates, Leo. Međunarodni odnosi socijalističke Jugoslavije. Beograd, 1976.

- Петрановић, Бранко. Југословенско искуство српске националне интеграције. Београд: Службени лист, 1993.

- Rimanelli, Marco. The A to Z of NATO and other International Security Organizations. Lanham-Toronto, Plymonth: Scarecrow press, 2009.

- Tadić, Bojana, Olivera Bogetić, Dragan Bogetić. Osobenosti i dileme nesvrstanosti. Beograd: Komunist, 1982.

- The Cambridge History of the Cold War, II, edited Melvyn P. Leffler and Odd Arne Westad. Cambridge: Cambridge University Press, 2010.

- Tripković, Đoko. Jugoslavija-SSSR 1956-1971. Beograd: Institut za savremenu istoriju, 2013.

- Verheyen, Dirk. The German Questions: A Cultural, Historical and Geopolitical Exploration. Boulder - San Francisko - Oxford, 1991.

- Vestad, Od Arne. Globalni hladni rat. Beograd: Arhipelag, 2008.

- Vukadinović, Radovan. Sila i interesi: Vanjska politika SAD. Zagreb: Centar za kulturnu djelatnost omladine, 1972.

- Vukadinović, Radovan. Evropska sigurnost i suradnja. Zagreb: Globus, 1976.

- Vukadinović, Radovan, Lidija Čehulić Vukadinović, Davor Božinović. NATO euroatlanska integracija. Zagreb: Topical, 2007. 


\title{
Резиме
}

Љубодраг Димић

\section{Југославија и безбедност у Европи 60-их година XX века (погледи, ставови, иницијативе)}

\begin{abstract}
Апстракт: Питање мира и безбедности у Европи је било једно од централних питања југословенске спољне политике током шездесетих година 20. века. Југославија је подржавала иницијативе у циљу обустављања и забране нуклеарних проба, уништења застарелог војног арсенала, неширења нуклеарног оружја, постизања глобалне безбедности, залагала се за признање граница на Одри и Ниси и указивала на потребу прихватања две немачке државе. Чланак је писан на основу југословенских и совјетских објављених и необјављених докумената и релевантне домаће и стране литературе.
\end{abstract}

Кључне речи: Југославија, Европа, СССР, САД, Хладни рат, безбедност, нуклеарно оружје, немачко питање, Јосип Броз

Током шездесетих година 20. века на међународној сцени је постојао велики број иницијатива усмерених ка одржању мира и стабилности. Велике силе су исказивале интерес за закључивање парцијалних уговора о контроли нуклеарног наоружања, започети су разговори о обустављању и забрани нуклеарних проба, уништењу застарелог војног арсенала, неширењу нуклеарног оружја, постизању глобалне безбедности итд. У таквим условима је и југословенски врх позиционирао сопствено мишљење, ставове и конкретне иницијативе о тим важним питањима европске будућности, сматрајући да је спољнополитичка стабилност кључни интерес југословенске државе. Југославија је почетком шездесетих истицала да поновно наоружавање СР Немачке сматра грешком, залагала се за признање границе на Одри и Ниси, указивала на потребу прихватања две немачке државе, апеловала на САД и СССР да седну за преговарачки сто и конструктивно разреше постојеће проблеме. Сма- 
трала је одлуку СССР-а о обнављању нуклеарних проба погрешном. После неуспелих преговора СССР-а и САД-а у Женеви, Југославија и СССР су 1962. постављали основе нових међусобних односа. Суштина разговора током посета Леонида Брежњева Југославији и сусрета са Јосипом Брозом Титом (24. 9. - 4. 10. 1962) огледала се у ставу да се односи морају продубљивати на реалној основи, постепено и без илузија. Сарадњи и безедности Европи Југославија је најдиректније доприносила и ангажманом на Балкану. Прихватила је иницијативе Румуније и Бугарске да Балкан буде претворен у „зону мира“, тј. „безатомску зону“, као део политике Источног блока да би се неутралисало постојање база са нуклеарним оружјем на простору Балкана и Јадрана, али је и скретала пажњу на неопходност успостављања што бољих билатералних односа између држава Балкана. Југословенска политика је била компатибилна иницијативама из ССССР-а и Источног блока чији је циљ било стабилизовање прилика у Европи и решавање „немачког питања“ на мирољубив начин и уз закључење мировног уговора који би санкционисао постојање две немачке државе, регулисао посебни статус Западног Берлина, а питање уједињења Немачке препустио споразумевању Бона и Берлина. Такви ставови су изношени у сусретима југословенског врха са делегацијама ДР Немачке, Пољске, Чехословачке и СССР-а. Свесна повезаности питања мира у Европи са ситуацијом на Медитерану, делегација Југословенске лиге за мир се на Конференцији представника мировних покрета медитеранских земаља, одржаној од 5. до 9. јула 1964. у Алжиру, заложила за денуклеаризацију Медитерана. Југословенски ангажман на плану безбедности у Европи дошао је до изражаја и децембра 1965. на XX заседању Генералне скупштине ОУН-а. Том приликом једногласно је усвојена резолуција бр. 2129 „Акције регионалног карактера ради унапређења добросуседских односа међу европским државама са различитим друштвеним системима", чији је један од предлагача била и Југославија. Југословенски дипломатски представници су наставили исту политику и на заседању Интерпарламентарне уније одржаном средином априла 1966. у Камбери. Тада су дали иницијативу о организовању конференције чији би циљ био проширење сарадње, зближења и узајамне помоћи међу државама са различитим друштвеним уређењем. Та иницијатива је једногласно прихваћена. 